\title{
Core Social Values in Governance and Politics
}

\author{
Tunde Ajayi [Ph.D] \\ Department of Political Science and International Diplomacy \\ University of Education, Science and Technology, Ikere - Ekiti \\ Ibitoye, Majekodunmi Olusesan [Ph.D] \\ Department of Political Science and International Diplomacy \\ University of Education, Science and Technology, Ikere - Ekiti
}

\begin{abstract}
For years, decades and generations, people have wondered how negative values like racism, anti-semitism, religious phobia and cultural disagreements crept into national politics and governmental policies. How did the United States of America [USA] and Britain build the infrastructure of race and denial of opportunities into the architecture of governance [against people of color]? How did the Islamic nations of the far middle east, Asia and North Africa build pervasive, corrosive and hostile anti-West sentiments into the structure of their respective nation-states? Pundits and analysts have attempted, through behavioural theories and neo-observationist paradigms to explain the infiltration of societal sentiments and core values of leaders into the politics and governance of nations. In this write-up, we shall attempt to show how the dominant Fulani values, the Yoruba egalitarianism and the Igbo republican beliefs found expression in the politics and governance of Nigeria. This paper also devoted some time to other nations and climes where similar observations have been made. The archival and library documents from erstwhile regional governments of the past together with the cinematic and photographic evidence of the $1^{\text {st }}$ republic in Nigeria provided abundant evidence for the conclusion herein. Nnamdi Azikwe, Obafemi Awolowo, Ahmadu Bello and Aminu Kano all typified the core values of their respective ethnic groups and each of them carried such values into politics and governance. However, such core values are not common among the new breed politicians, thus, this paper recommends good values of discipline, honesty, integrity, transparency, justice, e.t.c, among the present political class.
\end{abstract}

Keywords: Core values, Societal sentiments, Dominant culture, Governance and Politics.

DOI: $10.7176 /$ RHSS/11-23-03

Publication date: December $31^{\text {st }} 2021$

\section{Introduction}

At a public lecture in year 2020, Keneth Enebeli, who represented the Anambra State Governor (Willie Obiano), made comments which drew both applause and disapproval from participants. The central kernel of his contribution at the lecture was: Until current leaders infuse the Igbo core tenets and values into the central administration in Abuja, real development would elude the nation. The comment was considered ethnocentric by some, dishonest by few and outlandish by many. In truth and reality, history, political knowledge and sociology have established the fact that core social and behavioural values of people are always the bedrock of politics, governance and developmental pursuit. Indeed, the politics of Nigeria from as early as 1940's have been based on the tripodal core values of the Hausa-Fulani, the Yoruba and the Igbos. This paper attempts to establish the tripodal elements in the politics and government of Nigeria and even goes on to show that in other parts of the world, core societal values and beliefs are never far away from the pursuits of government, be it Europe, America or Africa.

There is no denying the fact that the scientific fields of physics and chemistry have produced vast, profound and limitless literature on atomic relationships, molecular movements, atomic behaviour and energy. In a spectacularly similar manner, modern day Social Sciences has produced extensive literature on linkages between governments, governance, politics, monarchy, democracies, the relationship between traditions, governance, value system, core social beliefs, etc. For reasons not fully explored or explained, analysts and social commentators have a profound fascination for writing about connections, relationships and nexus between human beings and even complex web of social structures and scientific matters. It is in such analysis that pure distillation of knowledge and simplification of issues gain public validation or resolution. In many cases and in various regions of the world, such writings even found valuable usage in judicial platforms, policing activities and the moral fabrics of given societies.

By core social values, we refer to the dominant and reigning socio-political ideas, within a given nationstate, which influence state policies and political paths adopted by governments. The insight of Alonge throws more light on the issue of core social values: these reigning ideas may come as offshoots of tradition, heritage, and culture or as derived opinions of the intelligentsia within the given state. There is nothing mathematical or precise about such values but are often pervasive and comprehensive in popular acceptance and perception. A 
nation's behaviour is profoundly affected by the perceptions, attitudes and values of various participants in the decision making process. The general disposition and concrete political attitudes of the elite are the results of interactions between personality factor and domestic political environment. All decisions makers possess a set of values, beliefs and opinions which govern them in their response to policies and practices [Alonge, 2011].

In Europe, the Jews are believed to be clannish, thrifty and socially exclusive thereby discriminatory and insular in kindness, assistance and relationships. The Germans are perceived to be mechanistic, and machinelike even in obedience of laws, devotion to duties and execution of tasks. The Arabs are largely thought of as manipulative, deceptive, duplicitous, given to anger, revenge and belligerence while the Indians are perceived to be sly but persevering, ready to apply short tactics like deceit and lies to gain advantage, extremely nationalistic and unwilling to accept foreign ideas until domesticated. These views are neither scientific nor thoroughly researched but they are popular views that affect intra and interstate relationships. [Dudley, 1971].

The Nigerian rigmarole with democracy seriously started in 1946 via the Richards constitution. The triumphs and defeats suffered by the operators of that constitution and the subsequent ones [meant to be an improvement] were mere trends of development in a heterogeneous society filled with different vibrant traditions and value systems begging for serious studies and sincere understanding.

It is particularly for the reason stated above that we find the conclusion of Charles W. Kegley, Jr. extremely relevant as our opening remark. In the eleventh edition of "World Politics: Trends and Transformation," Kegley stated that:

as the twenty-first century approaches its first decade, discussions have moved beyond the new world order into such subtle areas of hope, peace and rising prosperity in the affairs of nation-states and the use of "democratization theories rooted in core values of the states" to help defuse socio-political tension and seemingly intractable contradictions within polyglots and heterogeneous nation-states. But even as we say this, many people set their sight on the promise of a stable global future and many others concentrate on the dread of a global instability characterized by terrorism and wars [Kegley, 2007].

A comparative study of this nature would benefit heavily from the behavioural school of thought and the various theories therein. The modern observationist models would also throw more light on the issue of core values and dominant political tenets within sovereign nation- states. The deductions made from such models and theories, even when subjective, are likely to be valid and elucidating. Indeed, over the past six decades, the observationist models have been more successful in the areas of individual or collective human political tendencies. The models have also been extremely potent in the identification of social core values of society and ethnic groupings.

For us, the appeal of Kegley's declaration is more in his realistic understanding of the politics of democracies in African states with many traditional values often in conflict with some core values of the social groups within the same state. Indeed, it does appear seemingly obvious that the path of politics and the pursuit of political interest is never far away from the tree of tradition and values of the ethnic groupings. Moreover, the choice of the type of politics is dictated by the history of the people: belligerence, deceit, manipulative oration, grand-standing, expletives and threat, rigorous hard work, collaboration either sincere or insincere. The starting point here is that: a look at the history and traditions of Nigeria's major political contestants like Azikiwe, Ahmadu Bello, Obafemi Awolowo and Aminu Kano would reveal why each of them opted for the style of politics and politicking they became famous for. We may even go further to say that the core influences which determined their political styles also affected the effectiveness or competence of the government each of them individually superintended or supervised. It may therefore be true that societal traditions and core values are never far away from governance.

\section{Conceptualizing Values and Politics: \\ Values}

In spite of the fact that Nigeria is a country of diverse culture, there are common acceptable values across all the cultures. These values includes; hardwork, honesty, humility, love, diligence, industry, respect for elders and constituted authority, self-control, respect for one's life and that of others, among others [Okola, 1992]. Be that as it may, Makinde [2016] views core values of a society as those invisible attributes that influence interest, morals, pleasures, desires, likes, needs, lives and attractions. They are beliefs and feelings about what is important, right or wrong, good or bad and whether an object is desirable or undesirable. To Bolerin [2009] "values are beliefs and ideas which individuals consider dear and acceptable... values are part of life right from the period of infancy to adulthood". Again, UNESCO [2010] posits that values are generally long term standard or principles that are needed to judge the worth of an idea and action. This means that values provides the criteria by which the learner or society can decide whether something is good or bad, right or wrong. 


\section{Politics}

Harold Lasswell [1930] an American Political Scientist defines politics as "who gets what, when and how". In other words, politics is concerned with which group of people get what resources at what time and in which manner. For Oscar Ameringer as cited in Akinlade and Ibitoye [2003] sees politics as "the gentle act of getting vote from the poor and campaign fund from the rich by promising to protect one from another". This definition attempt to dichotomize the act of politics by showing a sharp distinction between the rich and the poor, thereby making such relationship an asymmetrical one. Max Weber [1947] a German Political Sociologist defines Politics as "striving to influence the distribution of power either among the states or among the groups within a state".

A Nigerian scholar, Okwudiba Nnoli [1986] perceives politics as concerned with all activities that are directly or indirectly associated with the seizure, consolidation and use of state power. This definition emphasizes the power-centric concept of politics but it is not limited to it. A leading American Political Scientist, David Easton [1960] put it more succinctly as he defines politics as the "authoritative allocation of values in the society". This Eastonian definition is considered relevant by the contemporary Political Scientists because it focuses on the political activities rather than institutions. According to him, the authoritative allocation is the kind of activities that one should be interested in. The proposition is that in every society, values are desired. That is, people have diverse interests and these must be allocated or distributed by someone or something.

Finally, politics is seen to be concerned with the activities of the institutions of the state or government as well as any aspect of the society that overtly or covertly affects the operation of the institutions. In other words, politics is all about the functions of government and behaviour of the individuals or groups that are likely to affect the cause and conduct of the government as in voting, political party or in exerting influence in other way on those that are responsible for the allocation of values and scarce resources in the society [Akinlade and Ibitoye, 2003]

\section{Theoretical Framework: Failed State Theory}

This paper adopts Failed State Theory in order to explain the incidences of value/moral decadence in Nigeria as exhibited in the lives of our modern day politicians in contrast to what was obtainable among the likes of Nnamdi Azikwe, Obafemi Awolowo, Ahmadu Bello and Aminu Kano. The character of a non-failed state is enshrined in sections 14 and 15 of Chapter II of the 1999 Constitution of Nigeria[as amended] that "Nigeria shall be a state based on the principles of democracy and social justice, provide adequate infrastructural facilities and abolish all corrupt practices and abuse of power". On the other hand, a failed state refers to a government that has become incapable of providing the basic functions and responsibilities of a sovereign nation such as military defence, law enforcement, justice, education and economic stability. Common characteristics of a failed state also include; civil violence, corruption, crime, poverty, illiteracy and crumbling infrastructure. Even if a state is functioning, it can still fail if it loses credibility and the trust of people [https:/www.thoughtco.com].

Furthermore, Nguyen [2000] and Amoda [2009:19] as cited in Adedoyin [2016] identified the following as the characteristics of a failed state;

(i)High rate of traditional and white collar crimes.

(ii) Corrupt governance and abuse of office.

(iii) Inadequate internal and external security.

(iv) Incessant intra and inter ethnic and religious violent and conflict.

(v) Inability to sustain physical force on the citizenry.

A careful analysis of the characteristics of a failed state as mentioned above, shows clearly that Nigeria could be described to some extent as a failed state because of the prevailing situation threatening the corporate existence of the most populous nation in Africa otherwise known as the "giant" of Africa .

\section{African Sociologists and Their Comments on Tribal Values and Politics}

Prof. Omafome Onoge, arguably the most prolific writer, thinker and African sociologist of 1970 to 2000, had a lot to say about the central values that propelled the politics of the three major tribes of Nigeria [Yoruba, Igbo and Hausa-Fulani]. To him, the Igbos are, by culture and social practice, very republican and would rather debate issues at public squares than allow unknown forces decide paths for people to follow. The Yorubas are fiercely egalitarian in culture and social settings. As a matter of fact, the greatest political structure created by the wisdom of the tribe gave just enough power to the monarch to coordinate but not to oppress or abuse the underprivileged members of society.

In the Northern part of Nigeria, the phrase Hausa-Fulani is the convenient creation of the ruling elite which does not refer to any tribal group or ethnic reality in the North. In fact, the phrase is political: the closest meaning is to see it as the Fulanis who speak Hausa language for the purposes of social control, power consolidation and mystique creation across the country. The Fulanis, by history and social settings in Nigeria, are emigrants who through the Usman Dan Fodio wars and cunning gained political ascendancy in the 
Hausanawa regions of the North. The Fulanis have been variously described as story tellers, constantly moving and unforgiving of infraction and insults from outsiders and from within. The core values which they have exported into local politics are: building of vital friendships, adoption of chosen persons as fraternal colleagues, the use of big stick to keep the majority of persons under check and the use of Islam for mass mobilization and manipulation.

David Williams, the narrator and author of the biography on Alhaji Shehu Shagari. The Life of Shehu Shagari: President and power in Nigeria-had revealing things to say about the predominantly Fulani society that produced Shagari and his political mentor, Ahmadu Bello. He described and explained the main tradition of the Fulani society, right from the time of Shaikh Utman Dan Fodio, the Sokoto Empire, the various Southern movements of the Fulani groups in Peul, Fulbe, Fourah from Senegal, Cameroon and Futo Toro down to modern day Nigeria. In graphic and compelling measure, he described the collective phobia and underlining fear of the Fulani minority, especially when the British arrived at the colonial Northern Nigeria. Shehu Utman dan Fodio, the Shaikh was a Fulani and a scholar of repute at his time. The movement he started was not ethnic, just as the wars he initiated has combatants from all ethnic groups in the area. Nor was the Jihad simply a war between Muslims and non-Muslims; it represented a revolutionary movement inside a traditional society which was Islamic in nature. However, as governance took over from the Jihad, the Shaikh's principal lieutenants who included members of his family, were also Fulani, as were most of his "Flag bearers", who he sent to replace so many Hausa rulers. So, it has been often asserted that the Jihad was a revolt, against the oppressive Hausa overlords, resulting in a system which in time made the Fulani themselves oppressive overlords of the Hausa peasantry.

With the new task of rulership and governance, the numerically inferior Fulanis realized that only vigorous cultivation of social friendships and the concentration of the instruments of violence in Fulani hands could sustain them in this new superior position of leadership. From the early 1900, every Fulani man became persuaded and trained in the art of gaining loyalty and obedience through friendship and cultivation of affection from others. It is therefore not surprising that Shagari, during his time as federal minister in the first republic under Tafawa Balewa, cultivated friendships that lasted and paid unbelievable dividend for Shagari when he became president in 1979 .

The import of the lengthy analysis above can hardly be missed by students and masters of Nigerian political development and politics. In the past 100 years, the Feudal North, also known as the Fulanis and their adopted friends have kept faith with this core value and tradition. These values have been lifted and thrown in government and governance under them-Tafawa, Gowon, Shagari, Muritala, Babangida, Yar'adua, and Buhari. However, if the relationship between contemporary beliefs and politics is true in Nigeria, then, it should be observable in other nations of Europe, North America, Latin America, Oceania, Soviet Union, Asia and Middle East. In fact, the assertion that tradition and core societal values play important roles in politics and governance can only be considered a scientific theory if similar trends are observable in other sovereign states.

\section{Tradition, Core Values and Politics in Other Climes}

Many of the principal theories used as explanation for colonialism and imperialism have turned out to be more untrue and not supported by known facts. The Juridical theory, the Civilization theory, the scientific doctrine of imperialism and even the theory of Profit have all been shown to be more speculative and self justifying than being thoroughly dissective and truly explanatory. As declared by Williams, the colonial acquisition of Britain in African as well as the imperialist thrusts that followed full slave trade were the direct products of the core values of United Kingdom[ $\mathrm{U} \mathrm{K}$ ] at that period: trade and great power rivalry. The discovery of the steam engine and its subsequent progressive refinement gave Europe a unique advantage in sea faring. This advantage led to superior geographical knowledge and the discovery of paths to other places and nations. For over 200 years, the great powers of Europe [Britain, France, Germany, Spain, Netherlands and Italy] were involved in an obscene rivalry of supremacy. The desire to remain relevant and affluent in the politics of great European powers together with the desire to expand trading posts and sources of raw materials for vibrant factories within European homeland led to the politics of colonialism and the monster of imperial structure. Again, after 300 years, raw imperialism and slavery lost its allure and appeal and so, neo- colonialism and dependency took over not only in commerce but essentially in all European governments and governance principles. For Williams therefore, the preeminent culture and core values of Europe in the $16^{\text {th }}$ century were the essential social forces that led to the colonial escapade, imperialism and even trans-atlantics slave trade.

Schlesinger, Jr. [1966] made the same point and observation in his Pulitzer prize-winning book- "A Thousand Days: John F Kemedy in the White House" - According to him, the American war of liberation became unavoidable or inevitable the moment "no tax without representation" became the central and dominant core values of the nascent America society, despite the known and well documented linkage between United Kingdom and the major founders of the new States of America. It was such a core value and central political belief that the elders, leaders, opinions moulders and youths of United States were prepared to pursue and 
implement either in peace or through war.

John F. Kennedy [JFK] would personally have preferred to be remembered for expanding the rights of citizenship and reducing the oppression of African-Americans but he spent most of his one thousands days in office dealing with the three issues that formed the core values of his time, values that emerge from their history, culture and reality of American existence: the rivalry or struggle between capitalism and communism; the management of an emerging industrial society - a problem that is not rooted in ideology but in administration and thirdly how to maintain the economy so that it continues to move ahead to ensure the pride of place of the United States .

The point being made by Schlesinger [1966] therefore is that personal preferences, individual wishes and programmes tend to take back seats or second row to the collective core values of the society especially in democratic governments. The President would have loved to attend to civil rights and civil liberty movements beyond what he did but the apparatus of government had been fully tuned to how to defeat and subvert Soviet Union, how to maintain the growing economic prosperity of the United States of America and how to effectively manage and govern the highly scientific sprawling cities being created by innovative and vibrant capitalism. From 1944 or thereabout, the central focus of the American democratic system and the generality of the people was the destruction of the "demonic, atheistic imperial polyglot called Soviet Union with its practice of socialistcommunism." Along with the American allies, a minimum of nine organizations were created, well funded and given specific instructions to undermine, investigate and unravel the Marxist system in Soviet Union. By the time JFK took his oath of office in 1961, the core value and societal culture was the disdain for Soviet Union and the overriding desire to promote capitalist democracy as superior in all ramifications, over and above every Marxist undertaking in security, productivity, armament, space exploration, medicine, sports, quality of life, social harmony, etc . The general disapproval of anything Marxist was the signature tune of not only the American politicians but the favorite topics of writers, activists and the civil society. All U.S. Presidents of the post war era [1945] operated on this central core value which, indeed, became their strongest social norm. Nixon, Kennedy, Reagan, Bush and even Bill Clinton, though of different political affiliations, all infused their respective politics and government with the anti-Marxist core value of the society.

Similar parallel can be drawn about British politics and government rooted in tradition and core social values from time to time. After 30 years of war in Europe between major ethnic groups, the West Phalian treaty of 1648 marked the beginning of nation-state as we have it today; the rejection of extreme dictatorial monarchical rule, the bifurcation of christianity from statehood and the codification of new rules of inter-state relationships. Thenceforth, statehood became available to only settled and well demarcated ethnic societies: England, Scotland, Poland, Italy, Germany, Austria, etc. Of all the nomadic groups in Europe, only the Gypsies opted to remain wanderers and nomadic and therefore stateless. The four keys tenets were eventually translated in the various constitutions and practices of government all over Europe. In short, the thirty years of war was promoted by popular social ideas and beliefs; these beliefs were considered worthy of fighting and dying for. At the end of the war, the definition of state changed, the ownership structure changed, the political parties that emerged took their biggest cues from the treaty of West Phalia while access to leadership and political positions mandatorily fell on those who shared the core values of the given society and were properly labeled politicians.

Even in Britain, the profound and remarkable roles played by trade Unionists in the choice of development path for the economy of England obtained for them a major platform in the politics of Westminster. Till tomorrow, the struggle for power remains essentially between the conservatives and the Labour Party. The British labour leaders and organized Unionist cemented their pole positions in party politics through their robust contributions of theories like Labour Theory of Value, Laisser Faire doctrine, Land Use and Tenure, Labour Market Analysis and labour relations. In Britain, labour leaders and Unions made significant contributions to the day-to-day political discourse, especially at the end of the First World War in 1919; an impressive contribution that earned them the privilege of forming one of the two major political parties in England. Here again, we see the powerful nexus between core societal value and politics.

\section{Traditional Values and Political Options in Nigeria}

The Igbos of Nigeria are purely republican in nature and by tradition; important societal decisions are taken at market places or at the town halls. As noted by late Prof. Omafume Onoge, a foremost sociologist of repute:

Studies of many republicans' societies have revealed that three major psychological traits are in abundance; strong individuality, inter-personal competitiveness and oratorical skills for leadership aspirations. [MAMSER AT FOUR: LECTURE SERIES, 1991]

A look at the major politicians from Eastern Nigeria shows that virtually all of them have the gift of the garb: Opara, Mbadiwe, Nwolise, Nnamdi Azikwe and others. A speech of ten minutes would be laced with five proverbs, two anecdotes and four ancestral praises. In the case of "Zik of Africa," there is the additional showoff of his unique understanding of English language. According to Williams [1982] Zik represents, [till today] 
the brand and type of politics the Igbos are known for. He was a multi linguist, very comfortable with English and Hausa and more than average understanding of Yoruba. He knew when to be cold, tepid or hot and could migrate from one end to the other in his analysis of the ills of his fatherland, with ease. Zik's showmanship only surfaced to convince his listeners that his success was not limited to the local enclave.

In 1989, the defunct Centre for Democratic Studies in Abuja showed video clips of 1957 and 1958 that depicted the Igbo version of politics: flowery language, huge analysis of the Nigeria problem, scanty preferment of solutions, lots of proverbs and wise - crackers and showoff in English language. Chief Nnamidi Azikwe had a rally at Onitsha market and the reception was huge, with sporadic shuts of Zeek, Zeek, Zeek !!!. His speech touched virtually all the major problems of the polity and just when he was about to end and wanted to advise the people that birds of the same plumage must learn to flock together: he said "apes of the same ontological identity conglomerate together at the lowest hibernating proximity". He got the loudest applause despite the fact that none of the traders at the market understood the meaning of the expressed words. Zik had spoken above their heads but he had also shown himself as a product of the white-man's school, the dream and prayer of all women of Igbo land at that time.

The choice of this verbous oratorical approach to politics by virtually all politicians from the South-East can be traced to the republican tradition of the Igbos and their core value which allocated maximum priority to Western education and European life [men of timber and caliber].

In 1958, Mapo hall in Ibadan was filled to the brim by women who came to see and listen to Zik who was hugely popular in the West then. He had done the usual analysis of the ills of Nigeria in flowery prosaic language with appropriate proverbs and anecdote and attempted to conclude that colonialism, imperialism and Trans-Atlantic slave shortchanged the development of Africa. Zik concluded in the following words - "the profound subjective response and impositions by our colonial hegemonists of the tripodal evils of imperialism, slavery and vestiges of colonialism on a global political, socio economic and moral state of anaemic dependence in Africa metamorphosed into reduction of confidence and capacity." Again the applause was deafening but the women only clapped for grammar and not for message or comprehension.

Anthropologist and sociologist agree that the Yoruba tradition and way of life may best be described as egalitarian, fiercely protective of natural rights and human liberties. Even the greatest political structure created by the Yorubas only gave adequate powers to the Alaafin of Oyo but refused to allow imperial dictatorship of any form. In such societies, the path of politics is usually dotted by objective analyses, equally painstaking prescription of solutions and remedies and an elaborate commitment to a search of leadership with egalitarian qualities. The emergence of Chief Obafemi Awolowo as the leader of Yoruba politics followed this observable trend. The pursuit of free education, free medical services, abundant production of food through farm settlements and other programmes of Awolowo's administration were designed to keep the Yoruba nation progressively egalitarian. This type of politics involves hardwork, vigorous mental analyses and studious recruitment of likeminds to build consensus for planning, programme activation and results evaluation. This is the type of politics you will find in England, and Wales and Germany. This may be the reason why Harold Wilson [former Prime- Minister of U.K] openly declared that if Chief Awolowo had been born in Britain, he would have served as United Kingdom Prime -Minister earlier than Wilson's tenure in the office [Sunday Times August 25, 1961]. Awolowo was the complete embodiment of this type of politics. To him, politics is supreme sacrifice of mental and physical labour every day, every hour, every minute. It demands all forms of sacrifice and purification and a great deal of thinking and collectivization which make it impossible for such politicians to engage in frivolous socials like partying, dancing, clubbing, womanizing, etc. [My March Through Prison].

Since this work has been done mainly through qualitative methodology, historical records analysis and participatory observation in analyzing behaviour and facts, we can confirm that replacements for the first generation politicians have been extremely difficult. The West has not produced another Awolowo while the shoes of Azikwe have been too big for new politicians from the East. Indeed, no politician, from the North, especially the Fulani enclave, has been able to match the political wisdom and innate maturity of Ahmadu Bello. As said in proceeding pages, the Fulani politics had been largely dependent of cultivation of friendships and easy adoption of others into their ambience. Gowon, Babangida and Muritala Mohammed were all adopted and nurtured as friends of the Fulani hegemonists. The effectiveness of the Fulani system can further be appreciated by the historical fact narrated by Ali Yahaya (1992).

"Shortly before the independence of Cameroon, France decided to conduct a referendum in the English speaking part of Cameroon i.e. the western side of Cameroon. The Sadauna [Ahmad Bello] relocated to upper part of the Cameroon. Within six [6] months, the Sadauna had penetrated the place, endeared himself so much to the leaders, politicians and traditional opinion moulders of the people. The Sadauna province of Gongola State [now Adamawa] by $80 \%$ opted to join Nigeria. The southern part of the same axis, left to Zik to coordinate, had deep suspicion and distrust for the Igbo personality and traits that they voted to remain in Cameroon by $76 \%$. The popular and effective mantra used against Zik was "move to Nigeria and be dominated. Stay in Cameroon for liberation and equality". In contrast, the effective mantra in the North west was "friendship is everything, we 
stay with our friends in Nigeria".

\section{Conclusion/Summary}

Nigeria inherited from its political avatars three main strands of politics which all emanated from local traditions and core social beliefs of the participating societies:

i. Politics of pontification, oration and showmanship.

ii. $\quad$ Politics of cultivated friendships and adoption of worthy persons.

iii. $\quad$ Politics of rigorous analyses and factual presentation.

As noted by Akilaiya [2005] the three types have become truly Nigerian styles as new breed politicians freely choose which type to adopt and practice. Politics of friendship and adoption is no longer the exclusive preserve of the North while showmanship and verbous pontification has found its way into other zones outside the Southeast. However, the cerebral rigorous analytical type has found it virtually impossible to recruit newcomers. The high level of discipline, commitment and hardwork required for that type of politics appears to be frightening to new breed politicians. Few politicians of the new millennium can claim to have the mental and character attributes of late Chief Obafemi Awolowo. It is perhaps this character deficit that is responsible for the snail-like movement of real development under our current democratic dispensation.

\section{Suggestions}

Every society is built on the spirit of solidarity through the cohesion of ideas [values] and mutual understanding. This often ensures order, stability, peaceful relationship, continuity, development and sustainability. This therefore demands for a careful selection of the values that would help to integrate the society and promote the mutual relationship and understanding among the different ethnic groups thereby producing a better society to live in. Thus, the following suggestions are recommended;

* The concept of value re-orientation that focuses on refining the Nigeria politicians and the entire Nigerian citizens must be embraced.

* Nigeria politicians must also embrace high level of discipline, commitment, dedication, hardwork, e.t.c, that will lead us to the path of greatness.

* Continuous enlightenment campaign on the right values for national peace and progress must be encouraged.

* Leaders should lead by examples so that the youths can learn from them those values that are worthy of emulation.

* Introduction of citizenship/leadership training at all levels of government [Federal, State and Local governments] in order to prepare them for the future challenges.

\section{References}

Adedoyin, A. [2016]. Corruption and Value re-orientation. Journal of National Association of Women in Colleges of Education. 21(1), 5

Akilaiya, A. [2005] Awo: The Avatar. Ifaki Ekiti: Sentry Books Nig Ltd.

Akinlade, M.T and Ibitoye, M.O [2003] Introduction to Political science. Excels productions. Akure

Alonge, F. K. [2011] Dynamics of Government in Nigeria. Ibadan: University Press Plc.

Amoda, J.M [2009] "The Conceptual States of the Phrased Failed State". The Vanguard. December. P19

Awolowo, O. [1985] Adventures in Power: My March Through Prison, Yaba, Lagos: Macmillan Nigeria Publishers Ltd.

Bolerin, D [2009] Introduction to Guidiance Services. Maiduguri: University of Maiduguri Educational Services.

Dudley,B.J [1971] Instability and Political Order: Politics and Crises in Nigeria. Ibadan: Ibadan University Press. Easton,D [1960] The Political System. New York: Oxford University

FGN [1999] Constitution of the Federal Republic of Nigeria Abuja: Government press.

Harold Lasswell [1930]Politics: Who Gets What,When and How. New York: Oxford University. https://www.thoughtco.com Assessed on the $12^{\text {th }}$ November 2021

Kegley, C. W. [2007] World Politics: Trend and Transformation. Belmont, Thomson Wadsworth.

Kuper, A and Kuper, J. (Eds). [1990] The Social Sciences Encyclopedia. London \& New York: Routledge.

Makinde, V.I [2016] Women Counselors as Change Agent for Value Re orientation in Nigeria Educational system. International Journal Of Educational Foundation and Management. Ekiti State University [IJFAMEKSU]10([1],238.

Mamser at Four: A Publication of the Directorate for Social Mobilization, 1991. In House Printers.

Max, M. [1947] The Theory Of Social and Economic Organization.New York:OUP

Nnoli,O [1986] Introduction to Politics. Lagos:Oxford University Press.

Okola, C.A [1992] Helping Children and Youths in a Society of De-stabilizes Traditional Values. In C. C. 
Ekennia [Ed] Counseling Spectrum 1[1],55

Oyediran, O. [1989] Survey of Nigeria Affairs. Lagos: Macmillan Nigeria Publishers Ltd.

Plano, J. C. \& Greenberg, M. [1989] The American Political Dictionary. New York: Holt, Rinehart and Wiston. Schlesinger. Jr, A. M. [1966] A Thousand Days: John F. Kennedy in the White House. New York: Forest Crest Book.

Sunday Times. August 25,1961.

UNESCO [2010] What is the Importance of Value Education? http:www.inference.com . Paris. Retrieved on the $13 / 11 / 2020$.

Williams, D. [1982] President and Power in Nigeria: The Life of Shehu Shagari: London, Frank Cass and company Ltd.

Yahaya, A.D. (1992). Social Transformation for self-Reliance: Proceeding of a National Conference. Fountain Publication. Ibadan. 